\title{
Whey Protein Concentrate and Gum Tragacanth as Fat Replacers in Nonfat Yogurt: Chemical, Physical, and Microstructural Properties
}

\author{
S. Aziznia, ${ }^{1}$ A. Khosrowshahi, A. Madadlou, and J. Rahimi \\ Department of Food Science and Engineering, Faculty of Agriculture, Urmia University, Urmia, Iran
}

\begin{abstract}
The effect of whey protein concentrate (WPC) and gum tragacanth (GT) as fat replacers on the chemical, physical, and microstructural properties of nonfat yogurt was investigated. The WPC $(7.5,15$, and $20 \mathrm{~g} / \mathrm{L})$ and GT $(0.25,0.5,0.75$, and $1 \mathrm{~g} / \mathrm{L})$ were incorporated into the skim milk slowly at 40 to $45^{\circ} \mathrm{C}$ with agitation. The yogurt mixes were pasteurized at $90^{\circ} \mathrm{C}$ for $10 \mathrm{~min}$, inoculated with $0.1 \%$ starter culture, and incubated at $42^{\circ} \mathrm{C}$ to $\mathrm{pH} 4.6$, then refrigerated overnight at $5^{\circ} \mathrm{C}$. A control nonfat yogurt and control full fat yogurt were prepared as described, but without addition of WPC and GT. Increasing amount of WPC led to the increase in total solids, total protein, acidity, and ash content, whereas GT did not affect chemical parameters. Increasing WPC caused a more compact structure consisting of robust casein particles and large aggregates. Firmness was increased and susceptibility to syneresis was decreased as WPC increased. No significant difference was observed for firmness and syneresis of yogurt fortified with GT up to $0.5 \mathrm{~g} / \mathrm{L}$ compared with control nonfat yogurt. Increasing the amount of gum above 0.5 $\mathrm{g} / \mathrm{L}$ produced softer gels with a greater tendency for syneresis than the ones prepared without it. Addition of GT led to the coarser and more open structure compared with control yogurt.
\end{abstract}

Key words: nonfat yogurt, whey protein concentrate, gum tragacanth, microstructure

\section{INTRODUCTION}

Fermented dairy products have been a major part of the diet of people around the world (Dave and Shah, 1998). Yogurt is a popular fermented milk product and has been produced for several thousand years (Lucey et al., 1997). The alleged hypercholesterolemic effect of milk fat and the desire to ensure overall good health have led consumers to demand reduced milk-fat dairy

Received November 19, 2007.

Accepted March 17, 2008.

${ }^{1}$ Corresponding author: aziznia.somayeh@gmail.com products, including yogurt, to reduce the risk of coronary heart disease (Sandoval-Castilla et al., 2004). The amount of total solids in the base milk, to a large extent, determines the physical and textural properties of the final yogurt product (Baig and Prasad, 1996; Jaros and Rohm, 2003). Because of reduction of fat and subsequently reduction of total solids content in low fat and nonfat yogurts, they exhibit weak body, poor texture, and whey separation unless various stabilizer blends or ropy strains of yogurt bacteria are used (Mistry and Hassan, 1992; Trachoo and Mistry, 1998). Several studies have been reported on the improving the physical, textural, and rheological properties of reduced-fat yogurts by incorporating the fat-replacers into the milk or manipulation of processing parameters.

Dannenberg and Kessler (1988a,b) studied the effect of various periods of time at temperatures ranging from 70 to $130^{\circ} \mathrm{C}$, to achieve a different degree of denaturation of $\beta$-lactoglobulin ( $\beta$-LG). They showed that the firmness and viscosity of nonfat yogurt increased and the amount of syneresis decreased as the level of whey protein denaturation was increased. Modler et al. (1983) investigated the effect of addition of 6 protein types (3 casein- and 3 whey-based products) at 3 concentrations $(0.5,1$, and $1.5 \%$ added protein) on the physical and sensory properties of skim milk yogurt. They reported that addition of increasing amounts of protein increased gel firmness and decreased syneresis. Mistry and Hassan (1992) reported that the use of high milk protein powder in the manufacture of nonfat yogurt provided a firm body and minimal whey separation product. High milk protein powder was manufactured from pasteurized skim milk using ultrafiltration, diafiltration, and spray drying as described in Mistry and Hassan (1991). Harte et al. (2003) studied the combined use of high hydrostatic pressure of the milk used and thermal treatment in milk for the manufacture of lowfat yogurt. They showed that yogurt made from skim milk subjected to 400 to $500 \mathrm{MPa}$ and thermal treatments exhibited increased elastic modulus and reduced syneresis when compared with yogurt from only thermally treated or raw milks. Application of whey protein concentrate, microparticulated whey protein, and modi- 
fied tapioca starch in reduced-fat yogurts and their effect on the microstructure and texture of yogurt was studied by Sandoval-Castilla et al. (2004). They showed that in yogurt supplemented with whey protein concentrate, the casein micelles were predominantly linked by particle-to-particle attachment in large chains with comparatively small interspaced voids, rather than by particle fusion into aggregates. In addition to nonfat dry matter, stabilizers are used in yogurt for 2 basic functions: 1) the binding of water and 2) promotion of an increase in viscosity (Tamime and Robinson, 1999). The effects of some stabilizers such as waxy maize starch, gelatin, xanthan gum/locust bean gum, low methoxy pectin, guar gum, locust bean gum, and $\lambda$-carrageenan on the microstructure and rheology of yogurt have been studied (Kalab and Emmons, 1975; Keogh and O'Kennedy, 1998; Fiszman et al., 1999; Everett and McLeod, 2005), but according to our searches, there is no report on the effect of gum tragacanth $(\mathbf{G T})$ on the rheology and microstructure of yogurt in the literature. Rahimi et al. (2007) studied the effect of this gum on texture of low-fat Iranian white cheese and reported that GT improved the rheological properties of texture in low-fat cheese.

Gum tragacanth is an exudate of shrubs of the Astragalus species located mainly in southwest Asia, especially in Iran and Turkey. This gum is generally recognized as safe and has been used in a broad range of applications in foods, pharmaceuticals, cosmetics, and diverse industrial uses (Glicksman, 1983; Weiping, 2000). In addition, it is on the list of stabilizers that are permitted by Food and Agriculture Organization/ World Health Organization that could be used during the manufacture of yogurt (Tamime and Robinson, 1999). Gum tragacanth is a heterogeneous and acidic polysaccharide and is a mixture of 2 polysaccharides, of which the water-soluble component is called tragacanthin and the acidic water-swellable component is called bassorin (Glicksman, 1983; Sahin and Ozdemir, 2004). Bassorin accounts for 60 to $70 \%$ of the polymer and is based on polygalactronic acid, which is a linear chain of 1, 4 linked $\alpha$-D-galacturonic acid. Three types of side chains are known; namely, single $\beta$-D-xylopyranose and disaccharide units of 2-o- $\alpha$-L-fucopyranosyl-D-xylopyranose and 2-0- $\beta$-D-galactopyranosyl-D-xylopyranose (Yokoyama, Srinivasan and Fogler, 1988).

In this study, due to the nutritional and functional properties of whey protein concentrate (WPC; Havea et al., 2004) and function of hydrocolloids in enhancing viscosity and inhibition of syneresis (Sahin and Ozdemir, 2004), they were used for manufacture of nonfat yogurt. The objectives of the present paper were to study the effects of adding different concentration of
Table 1. Composition of skim milk powder (SMP) and whey protein concentrate (WPC) in the manufacture of yogurt mixes

\begin{tabular}{lcccc}
\hline Item & $\begin{array}{c}\text { Total } \\
\text { solids } \\
(\%)\end{array}$ & $\begin{array}{c}\text { Total } \\
\text { protein } \\
(\%)\end{array}$ & $\begin{array}{c}\text { Fat } \\
(\%)\end{array}$ & $\begin{array}{c}\text { Ash } \\
(\%)\end{array}$ \\
\hline SMP & 97.2 & 35.9 & 1 & 7.9 \\
WPC & 94.5 & 77.4 & 5 & 2.6 \\
\hline
\end{tabular}

WPC and GT as fat replacers on the chemical, physical, and microstructural properties of nonfat yogurt.

\section{MATERIALS AND METHODS}

\section{Yogurt Treatments}

Nine yogurt treatments were made as follows: control full-fat yogurt; control nonfat yogurt; nonfat yogurt fortified with 7.5, 15, and $20 \mathrm{~g} / \mathrm{L}$ of WPC; and nonfat yogurt fortified with $0.25,0.5,0.75$, and $1 \mathrm{~g} / \mathrm{L}$ of GT.

\section{Materials}

Milk and skim milk powder (SMP) were obtained from Pegah Dairy Company (Urmia, Iran). The WPC (Warrnambool Milk Products Ltd., Allansford, Victoria, Australia) and GT (Merck Science, Darmstadt, Germany) were purchased by Barnard Company (Urmia, Iran). Chemical compositions of SMP and WPC are given in Table 1.

\section{Yogurt Culture Preparation}

The DVS freeze-dried yogurt culture combination of Lactobacillus delbrueckii ssp. bulgaricus and Streptococcus thermophilus (CH1, Chr. Hansen's Dairy Cultures, Hoersholm, Denmark) was weighted (10 g) and added to $100 \mathrm{~mL}$ of sterile skim milk. One milliliter of this mixture was inoculated per $100 \mathrm{~mL}$ of yogurt mix.

\section{Preparation of Yogurt Mixes}

Fresh skim milk was standardized with cream of a determined fat content to $0.31 \%$ fat. For preparation of nonfat yogurts the milk was supplemented with skim milk powder $(2 \%)$ at $45^{\circ} \mathrm{C}$ and divided into 7 equal portions. Three parts were fortified with WPC $(7.5,15$, and $20 \mathrm{~g} / \mathrm{L})$ and 4 parts were fortified with GT $(0.25$, $0.5,0.75$, and $1 \mathrm{~g} / \mathrm{L}$ ). The GT was mixed with a few grams of skim milk, and then GT and WPC slowly were incorporated separately into the milk. Each different batches of mixture was agitated at 45 to $50^{\circ} \mathrm{C}$ using a mixer (Model HA-3020, Tokyo, Japan). Mixes were heated to $90^{\circ} \mathrm{C}$ for $10 \mathrm{~min}$ in a water bath, rapidly cooled to $45^{\circ} \mathrm{C}$, inoculated at $42^{\circ} \mathrm{C}$ at a rate of $0.1 \%$, dispensed 
Table 2. Codes of different yogurt mixes present in this study ${ }^{1}$

\begin{tabular}{ll}
\hline Code & Treatment \\
\hline CFY & Control full fat yogurt \\
CNY & Control nonfat yogurt \\
WPY7.5 & Yogurt stabilized with $7.5 \mathrm{~g} / \mathrm{L}$ of WPC \\
WPY15 & Yogurt stabilized with $15 \mathrm{~g} / \mathrm{L}$ of WPC \\
WPY20 & Yogurt stabilized with $20 \mathrm{~g} / \mathrm{L}$ of WPC \\
GTY0.25 & Yogurt stabilized with $0.25 \mathrm{~g} / \mathrm{L}$ of GT \\
GTY0.5 & Yogurt stabilized with $0.5 \mathrm{~g} / \mathrm{L}$ of GT \\
GTY0.75 & Yogurt stabilized with $0.75 \mathrm{~g} / \mathrm{L}$ of GT \\
GTY1 & Yogurt stabilized with $1 \mathrm{~g} / \mathrm{L}$ of GT \\
\hline
\end{tabular}

${ }^{1} \mathrm{WPC}=$ whey protein concentrate; $\mathrm{GT}=$ gum tragacanth .

into plastic containers (12 $\mathrm{cm}$ diameter $\times 10 \mathrm{~cm}$ height), and incubated at $42^{\circ} \mathrm{C}$ until the $\mathrm{pH}$ reached 4.6. This $\mathrm{pH}$ is the isoelecteric point for casein indicating complete coagulation (Baig and Prasad, 1996).

When the $\mathrm{pH}$ dropped to this point, fermentation was arrested by immersing the containers in an ice-bath maintained at $\sim 5^{\circ} \mathrm{C}$. The samples were then stored overnight at $5^{\circ} \mathrm{C}$, at which time the experiment was started. Yogurts were manufactured in triplicate in $1 \mathrm{~d}$, with each replicate using $2 \mathrm{~kg}$ of milk for each treatment. A control full fat (CFY) and control nonfat yogurt (CNY) were prepared according to described method but without addition of WPC and GT. Because of the high number of treatments, yogurt mixes were coded as shown in Table 2.

\section{Chemical Analysis}

The $\mathrm{pH}$ values of milk and yogurt mix samples were measured using a digital $\mathrm{pH}$ meter (microprocessor $\mathrm{pH}$ meter, model pH 537, WTW, Weilheim, Germany).The titratable acidity (TA) of yogurt was determined after mixing the yogurt sample with $10 \mathrm{~mL}$ of hot distilled water $\left(\sim 90^{\circ} \mathrm{C}\right)$ and titration with $0.1 \mathrm{~N} \mathrm{NaOH}$ using a $0.5 \%$ phenolphthalein indicator to an end point of faint pink color (Dave and Shah, 1998). The total solids, fat, total protein, and ash contents were estimated according to AOAC (1997) methods.

\section{Syneresis}

Syneresis (released whey) was measured by placing $100 \mathrm{~g}$ of yogurt sample on a Whatman filter paper (no. 4) setting on a top of a funnel. After $2 \mathrm{~h}$ of drainage at $7^{\circ} \mathrm{C}$, the volume of whey collected in a graduated cylinder was used as an index of syneresis (Tarakci and Kucukoner, 2003; Achanta et al., 2007).

\section{Firmness of Yogurts}

The firmness of fresh yogurt in the plastic containers was determined by the simplest fundamental test, uni- axial compression (Tunick, 2003) using a THE Universal Testing Machine (S-series bench U.T.M. Model H. 5k.S; Hounsfield Test Equipment Ltd., Redhill, UK) with a 500-N load cell. A cylindrical plunger with flat base $34 \mathrm{~mm}$ in diameter was attached to the moving crosshead.

The test was performed on the samples without removing them from their containers (Fiszman et al., 1999). The ratio of diameter of yogurt container to diameter of probe was 3.5:1. According to Amatayakul et al. (2006), it is generally accepted that the boundary or wall effects will diminish when the diameter of sample is at least 3 times greater than the diameter of the probe.

Yogurt samples were compressed at a constant penetration speed of $2 \mathrm{~mm} / \mathrm{s}$ to a depth of $35 \mathrm{~mm}$. Firmness was defined as the maximum force used in penetration (Amatayakul et al., 2006).

\section{Microstructure}

Yogurt samples were prepared for scanning electron microscopy following the method of Puvanenthiran et al. (2002) with modifications.

Samples $(\sim 3 \mathrm{~mm} \times 3 \mathrm{~mm} \times 1 \mathrm{~mm})$ were taken from below the surface and were fixed in $2.5 \%$ glutaraldehyde (Merck Science) for at least $1 \mathrm{~h}$. The fixed samples were then washed in distilled water for several times. This procedure removed lactose and other water-soluble substances (Kalab and Harwalkar, 1973). Samples were then dehydrated using a series of increasing ethanol concentrations $(20,40,60,70$, and $90 \%)$ finishing with 3 changes of absolute alcohol. Then pieces were mounted on aluminum stubs by silver paint, dried to critical point, and coated with gold for $6 \mathrm{~min}$ in a sputter-coater (type SCD005; Baltec Inc., Balzers, Switzerland). Photomicrographs were recorded at magnification of 2,800, 3,000, and 7,000× using SEM (XL Series, model XL30; Philips, Eindhoven, the Netherlands) operated at $15.0 \mathrm{kV}$.

\section{Statistical Analysis}

The experiments were carried out in triplicate and the results were submitted to the ANOVA using the GLM procedure of the SPSS (version 9.0, SPSS Inc., Chicago, IL). The means comparison was performed with the Duncan test at $P<0.05$.

\section{RESULTS AND DISCUSSION}

\section{Composition of Yogurt Mixes}

The averages of total solids, fat, protein, and ash contents of different yogurt mixes are shown in Table 3. 
Table 3. Mean $( \pm \mathrm{SD})$ of chemical composition of control yogurts, yogurts produced with whey protein concentrate (WPC) and gum tragacanth $(\mathrm{GT})^{1}$

\begin{tabular}{|c|c|c|c|c|c|c|c|c|}
\hline Item & $\begin{array}{c}\text { Total solids } \\
(\%)\end{array}$ & $\begin{array}{c}\text { Total protein } \\
(\%)\end{array}$ & & $\begin{array}{l}\text { Fat } \\
(\%)\end{array}$ & $\begin{array}{l}\text { Ash } \\
(\%)\end{array}$ & & $\begin{array}{l}\mathrm{pH} \\
\text { (b) }\end{array}$ & Acidity \\
\hline \multicolumn{9}{|l|}{ WPY } \\
\hline $\mathrm{CFY}$ & $13.20^{\mathrm{a}} \pm 0.12$ & $3.87^{\mathrm{e}} \pm 0.10$ & $3.10^{\mathrm{a}}$ & ${ }^{\mathrm{a}} \pm 0.06$ & $0.91^{\mathrm{d}} \pm 0.01$ & $4.46^{\mathrm{a}}$ & \pm 0.21 & $1.12^{\mathrm{d}} \pm 0.01$ \\
\hline $\mathrm{CNY}$ & $11.30^{\mathrm{d}} \pm 0.21$ & $4.02^{\mathrm{d}} \pm 0.03$ & $0.31^{\mathrm{b}}$ & \pm 0.01 & $0.98^{\mathrm{c}} \pm 0.01$ & $4.37^{\mathrm{b}}$ & \pm 0.11 & $1.16^{c} \pm 0.03$ \\
\hline WPY7.5 & $12.02^{\mathrm{c}} \pm 0.70$ & $4.54^{\mathrm{c}} \pm 0.17$ & $0.30^{\mathrm{b}}$ & $\mathrm{b} \pm 0.02$ & $1.02^{\mathrm{b}} \pm 0.05$ & $4.33^{\mathrm{b}}$ & \pm 0.17 & $1.19^{b} \pm 0.01$ \\
\hline WPY15 & $12.79^{\mathrm{b}} \pm 0.41$ & $5.11^{\mathrm{b}} \pm 0.41$ & $0.32^{\mathrm{b}}$ & \pm 0.01 & $1.04^{\mathrm{ab}} \pm 0.10$ & $4.29^{\mathrm{b}}$ & \pm 0.24 & $1.24^{\mathrm{a}} \pm 0.07$ \\
\hline WPY20 & $13.19^{a} \pm 0.52$ & $5.52^{\mathrm{a}} \pm 0.20$ & $0.31^{b}$ & ${ }^{b} \pm 0.07$ & $1.05^{\mathrm{a}} \pm 0.07$ & $4.29^{b}$ & \pm 0.30 & $1.22^{\mathrm{ab}} \pm 0.03$ \\
\hline \multicolumn{9}{|l|}{ GTY } \\
\hline $\mathrm{CFY}$ & $13.20^{\mathrm{a}} \pm 0.12$ & $3.87^{\mathrm{a}} \pm 0.10$ & $3.10^{\mathrm{a}}$ & ${ }^{a} \pm 0.06$ & $0.91^{b} \pm 0.01$ & $4.46^{\mathrm{a}}$ & \pm 0.21 & $1.12^{\mathrm{b}} \pm 0.01$ \\
\hline $\mathrm{CNY}$ & $11.30^{\mathrm{b}} \pm 0.21$ & $4.02^{\mathrm{b}} \pm 0.03$ & $0.31^{b}$ & $\mathrm{~b} \pm 0.01$ & $0.98^{a} \pm 0.01$ & $4.37^{\mathrm{b}}$ & \pm 0.11 & $1.16^{\mathrm{a}} \pm 0.03$ \\
\hline GTY0.25 & $11.31^{\mathrm{b}} \pm 0.73$ & $4.03^{b} \pm 0.05$ & $0.31^{\mathrm{b}}$ & $\mathrm{b} \pm 0.07$ & $0.96^{\mathrm{a}} \pm 0.11$ & $4.36^{\mathrm{b}}$ & \pm 0.04 & $1.16^{\mathrm{a}} \pm 0.08$ \\
\hline GTY0.5 & $11.28^{\mathrm{b}} \pm 0.46$ & $4.02^{\mathrm{b}} \pm 0.01$ & $0.29^{b}$ & $\mathrm{~b} \pm 0.11$ & $0.97^{\mathrm{a}} \pm 0.09$ & $4.34^{\mathrm{b}}$ & \pm 0.01 & $1.17^{\mathrm{a}} \pm 0.04$ \\
\hline GTY0.75 & $11.32^{\mathrm{b}} \pm 0.11$ & $4.01^{\mathrm{b}} \pm 0.17$ & $0.30^{\mathrm{b}}$ & $\mathrm{b} \pm 0.09$ & $0.99^{\mathrm{a}} \pm 0.07$ & $4.35^{\mathrm{b}}$ & \pm 0.06 & $1.17^{\mathrm{a}} \pm 0.09$ \\
\hline GTY1 & $11.31^{b} \pm 0.33$ & $4.01^{\mathrm{b}} \pm 0.12$ & $0.31^{b}$ & $\mathrm{~b} \pm 0.01$ & $0.97^{\mathrm{a}} \pm 0.03$ & $4.33^{\mathrm{b}}$ & \pm 0.02 & $1.18^{\mathrm{a}} \pm 0.06$ \\
\hline
\end{tabular}

${ }^{\mathrm{a}-\mathrm{e}}$ Means within an item (WPY and GTY) and column with the same letter are not significantly different at $P<0.05$.

${ }^{1}$ Yogurt codes are shown in Table 2.

The CNY had greater protein and ash content than CFY $(P<0.05)$. This difference related to the milk base used for preparation of yogurts. As the fat content of the milk was decreased, the moisture and protein contents significantly increased (Madadlou et al., 2005). Increased moisture content, probably cause an increase in the total amount of soluble minerals (Madadlou et al., 2005), which led to increased ash of CNY in contrast with CFY.

The CNY was shown to have greater titratable acidity and lower $\mathrm{pH}$ than CFY $(P<0.05)$. The greater value of TA in nonfat yogurt in comparison with full-fat yogurt was observed in another study (Bonczar et al., 2002). An increase in $\mathrm{pH}$ has been linked to an increase in the fat content in several other studies (Lucey et al., 1998; Shaker et al., 2000; Bonczar et al., 2002). It is probably due to the impact of fat content on the growth and activity of lactic acid bacteria in yogurt. This can cause the greater $\mathrm{pH}$ and lower TA of full-fat yogurts as compared with reduced fat yogurts.

Adding WPC influenced total solids, total protein, and acidity of different treatments of yogurt. As expected, by increasing the level of WPC, total solids, total protein, and ash content were increased. The greater acidities with the greater percentages of added protein would be expected because of the greater buffering capacity (Modler et al., 1983). On the other hand, WPC can serve as a source of peptides and amino acids when heat treated in yogurt mix (Dave and Shah, 1998). The increase in available nutrients from whey proteins may partially influence the growth of yogurt bacteria (Amatayakul et al., 2006) and possibly affected the changes in the TA and increased it in WPY. A similar $\mathrm{pH}(P>$ 0.05) of yogurt supplemented with WPC and CNY may be explained by the increase of buffering capacity of yogurt mixes due to the added WPC.

Yogurts supplemented with different concentrations of GT were similar $(P>0.05)$ in total solids, protein, fat, and ash content.

\section{Firmness and Syneresis of Yogurt}

Maximum force in compression and whey drainage data are shown in Table 4.

As expected, maximum force in compression of CNY was lower $(P<0.05)$ than that of CFY. Reduction of firmness due to the reduction of fat content has been reported by several researchers (Trachoo and Mistry,

Table 4. Mean $( \pm \mathrm{SD})$ values for firmness and syneresis of control yogurts, yogurts stabilized with whey protein concentrate (WPC) and gum tragacanth $(\mathrm{GT})^{1}$

\begin{tabular}{lll}
\hline Treatment & Firmness $(\mathrm{N})$ & $\begin{array}{c}\text { Syneresis } \\
(\mathrm{mL} / 100 \mathrm{~g})\end{array}$ \\
\hline WPY & & \\
CFY & $0.91^{\mathrm{d}} \pm 0.03$ & $21.00^{\mathrm{d}} \pm 0.83$ \\
CNY & $0.44^{\mathrm{e}} \pm 0.01$ & $41.25^{\mathrm{a}} \pm 0.56$ \\
WPY7.5 & $1.05^{\mathrm{c}} \pm 0.01$ & $36.87^{\mathrm{b}} \pm 1.06$ \\
WPY15 & $1.25^{\mathrm{b}} \pm 0.11$ & $27.16^{\mathrm{c}} \pm 0.73$ \\
WPY20 & $1.46^{\mathrm{a}} \pm 0.05$ & $29.06^{\mathrm{c}} \pm 0.21$ \\
GTY & & \\
CFY & $0.91^{\mathrm{a}} \pm 0.03$ & $21.00^{\mathrm{d}} \pm 0.83$ \\
CNY & $0.44^{\mathrm{b}} \pm 0.01$ & $41.25^{\mathrm{c}} \pm 0.56$ \\
GTY0.25 & $0.45^{\mathrm{b}} \pm 0.07$ & $40.10^{\mathrm{c}} \pm 0.75$ \\
GTY0.5 & $0.43^{\mathrm{b}} \pm 0.03$ & $40.19^{\mathrm{c}} \pm 0.11$ \\
GTY0.75 & $0.38^{\mathrm{c}} \pm 0.01$ & $44.70^{\mathrm{b}} \pm 0.77$ \\
GTY1 & $0.34^{\mathrm{d}} \pm 0.02$ & $47.15^{\mathrm{a}} \pm 1.01$ \\
\hline
\end{tabular}

${ }^{\mathrm{a}-\mathrm{e}}$ Means within a treatment (WPY and GTY) and column with the same letter are not significantly different at $P<0.05$.

${ }^{1}$ Yogurt codes are shown in Table 2. 

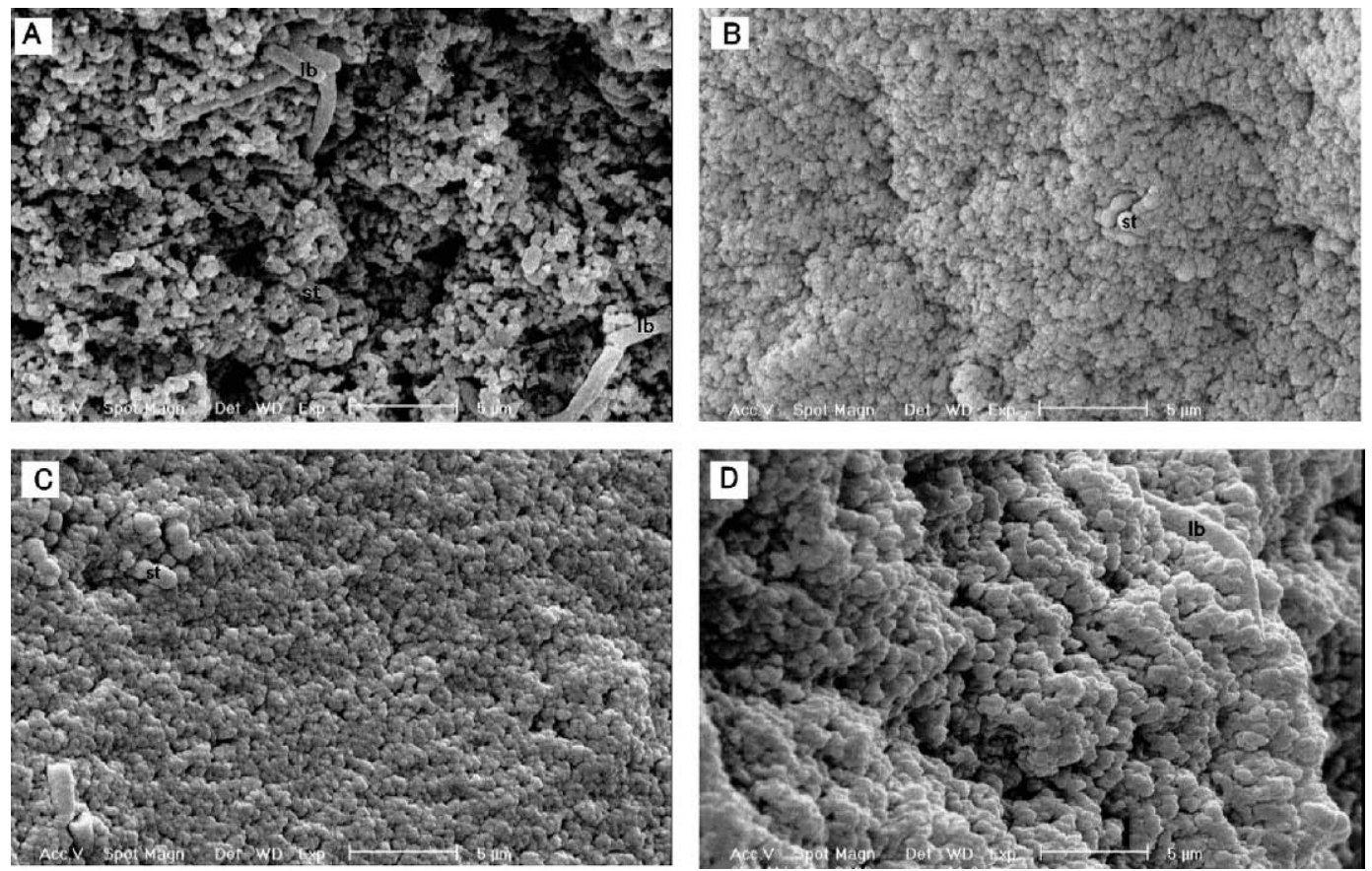

Figure 1. Scanning electron micrographs of yogurts stabilized with different concentrations of whey protein concentrate. A) CNY; B) WPY7.5; C) WPY 15; D) WPY20. Yogurt codes are shown in Table 2. lb = lactobacilli, and st = streptococci. Magnification is 3,000×. Scale bar $=5 \mu \mathrm{m}$.

1998; Sandoval-Castilla et al., 2004; Pereira et al., 2006). Greater total solids and positive interactions of fat globules with the gel network in CFY are the reasons for the greater firmness and lower syneresis $(P<0.05)$ of this treatment. By addition of WPC to the mix, its firmness was increased and syneresis was decreased $(P$ $<0.05$ ). Modler and Kalab (1983) showed that in yogurt fortified with $0.5,1$, and $1.5 \%$ of WPC, increasing the amount of WPC increased the firmness and decreased the susceptibility to the syneresis. Increased concentration (Modler et al., 1983; Modler and Kalab, 1983) in yogurt mix may lead to the increased bound water (Trachoo and Mistry, 1998) and larger protein aggregates (Puvanenthiran et al., 2002). These, consequently, increased the firmness of the resulting gel (Trachoo and Mistry, 1998).

There is a relationship between the microstructure of yogurt and firmness and susceptibility to syneresis (Modler and Kalab, 1983). Yogurts which have a denser structure and lower porosity exhibit more water retention capacity (Mistry and Hassan, 1992; Puvanenthiran et al., 2002). Though the yogurt supplemented with 20 $\mathrm{g} / \mathrm{L}$ of WPC had greater TS and water-binding capacity than yogurts supplemented with 7.5 and $15 \mathrm{~g} / \mathrm{L}$ of WPC, it had a greater degree of syneresis than WPY15. Although this difference was not statistically significant $(P>0.05)$, it could result from more the open microstruc- ture of this treatment that influences the whey-entrapping capability of the protein network.

Addition of GT up to $0.5 \mathrm{~g} / \mathrm{L}$ did not have a significant effect on firmness and syneresis of yogurt mixes. It was observed, however, that greater gum concentrations resulted in greater syneresis and lower firmness. Increasing amount of gum above $0.5 \mathrm{~g} / \mathrm{L}$ increased the syneresis and decreased the firmness $(P<0.05)$ significantly. These differences would be explained by the different microstructure of protein network. The coarser more open structure has a greater drainage than the finer network (Puvanenthiran et al., 2002). The lower firmness can be explained by more open structure of treatments enriched with GT than control treatments.

\section{Microstructure}

The microstructures of different yogurt treatments are shown in Figures 1 and 2. It can be seen that supplementation of milk with different concentrations of WPC and GT influenced the microstructure of yogurt treatments.

During acidification of milk, casein particles (as well as denatured whey proteins associated with the surface of micelles) aggregate into chains and clusters that are linked together to form a 3-dimensional network (Lucey et al., 1998; Pereira et al., 2006). Adsorption of whey 

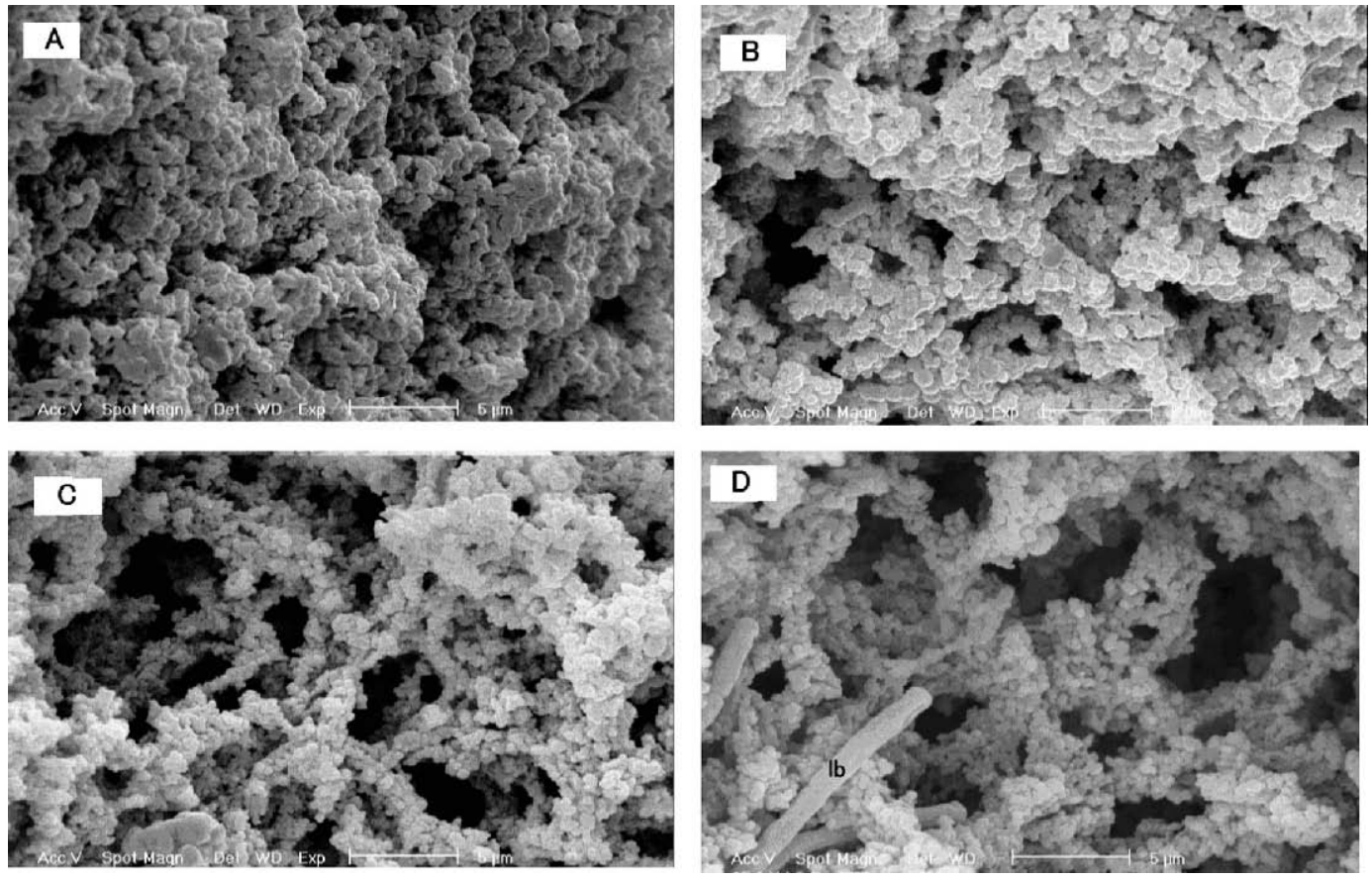

Figure 2. Scanning electron micrographs of yogurt stabilized with different concentration of gum tragacanth. A) GTY0.25; B) GTY0.5; C) GTY0.75; D) GTY1. Yogurt codes are shown in Table 2. lb = lactobacilli. Magnification is 3,000×. Scale bar $=5 \mu \mathrm{m}$.

proteins onto the casein micelles via the $\beta$-LG/ $\kappa$-casein complex and disulfide-linked aggregates between $\kappa$-casein and whey proteins prevents dissociation of the micelles and hence release of the $\beta$-casein molecules. This leads to an increase in particle size (Beaulieu et al., 1999; Schorsch et al., 2001).

Addition of whey protein could increase the diameter of particles (Guyomarc'h et al., 2003; Donato et al., 2007) and also saturate all of binding capacity of $\kappa$ casein to whey proteins, which leads to the formation of additional whey protein aggregates (Beaulieu et al., 1999; Puvanenthiran et al., 2002). These conditions appear to influence the formation of the network and consequently microstructural and rheological properties of yogurt. As can be seen in Figure 1, comparisons of the micrographs suggested that the microstructure of nonfat yogurt stabilized with $7.5 \mathrm{~g} / \mathrm{L}$ (Figure 1B), $15 \mathrm{~g} / \mathrm{L}$ (Figure 1C), or $20 \mathrm{~g} / \mathrm{L}$ of WPC (Figure 1D) was different from control yogurt. Increased concentration of WPC yielded the more compact structure consisting of fused casein particles and large aggregates. The protein structure is characterized by large, fused protein clusters close to each other extensively, and chains were not evident. These yogurts showed more dense protein matrix with lower porosity than CNY. Increasing WPC up to $15 \mathrm{~g} / \mathrm{L}$ made the protein matrix denser and reduced its porosity, but above this concentration, the protein network underwent more notable changes. The structure became more open with markedly lumpy texture than lower concentrations. Addition of whey proteins in excess proportion probably led to the formation of extremely large whey protein aggregates between casein particles, which altered the process of gel formation during acidification by increasing the distances between clusters and reducing the apposite association of them. This would indicate the differences between microstructure of yogurt supplemented with $20 \mathrm{~g} / \mathrm{L}$ of WPC in comparison with lower concentration of WPC. Singh et al. (1996) and Beaulieu et al. (1999) reported that the complexations of whey proteins do not only occur via the $\beta$-LG- $/ \kappa$-casein interaction but $\alpha$-LA $/ \alpha$ LA, $\beta$-LG/ $\beta$-LG, and $\beta$-LG/ $\alpha$-LA complexes could also be formed. This suggest that whey proteins present in excess proportions could lead to self aggregation of whey proteins. The occurrences of whey protein to whey protein interaction will increase at high levels of whey proteins. It is possible that formation of these nonmicellar large aggregates between casein clusters altered the process of gel formation and induced changes in microstructure.

As shown in Figure 2, the addition of GT to the milk notably changed the microstructure of yogurt mixes. Observation of the microstructure suggests that GTY0.25 (Figure 2A) and GTY0.5 (Figure 2B) had coarser compact microstructure than $\mathrm{CNY}$. The addition of greater concentrations of gum (Figure $2 \mathrm{C}$ and 

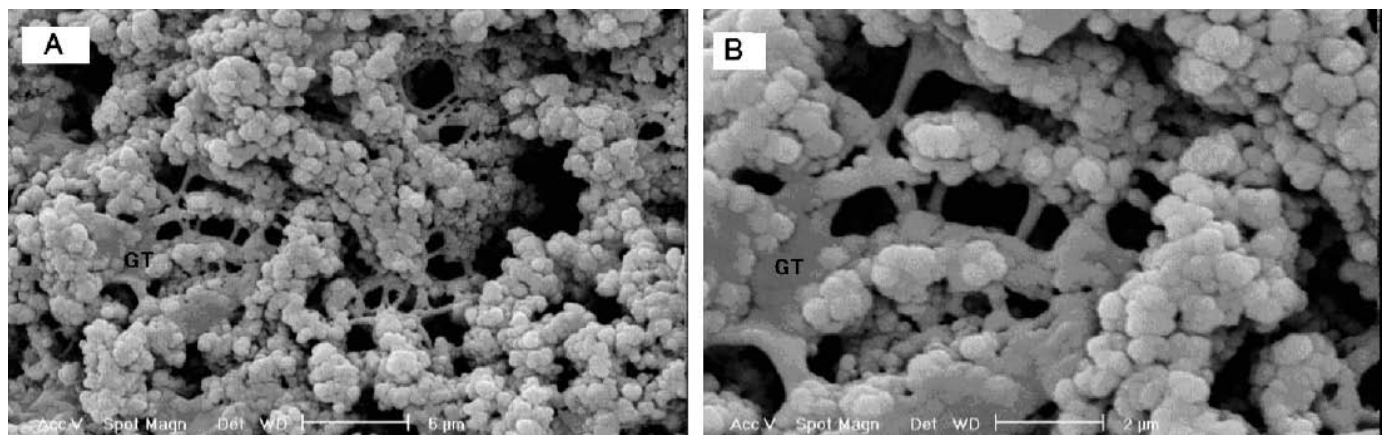

Figure 3. Scanning electron micrographs of yogurt network stabilized with $1 \mathrm{~g} / \mathrm{L}$ gum tragacanth. GT = gum tragacanth trains. Magnification is $2,800 \times$, scale bar $=2 \mu \mathrm{m}$ and $7,300 \times$, scale bar $=5 \mu \mathrm{m}$, for left- and right-hand micrographs, respectively.

D) led to the coarser and much more open structure than control. Probably the extensive rearrangements of protein particles during fermentation led to the formation of large pores and coarser structure in GTY.

Ionic hydrocolloids are generally carboxylated or sulfated (Syrbe et al., 1998). Gum tragacanth carries carboxylic groups (Yokoyama et al., 1988) and is an anionic polysaccharide. During acidification, when $\mathrm{pH}$ is lowered, the colloidal calcium phosphate will dissolve (Lee and Lucey, 2004). The solubilization of colloidal calcium phosphate may help by binding $\mathrm{Ca}$ to the polysaccharide and lead to the increased sensitivity of casein to extensive rearrangement and formation of larger pores and coarser structure. More compact structure of GTY0.25 and GTY0.5 than other concentrations may be because of bridging of casein aggregates by gum (Syrbe et al., 1998). By increasing the amount of gum to $1 \mathrm{~g} / \mathrm{L}$, the density of the matrix was reduced and spaces became larger markedly because of formation of loops and tails (Yokoyama et al., 1988) within the yogurt network.

Anionic polysaccharides that can interact with the positive charges on the surface of casein micelles are classified as adsorbing polysaccharides (Everett and McLeod, 2005) and by reduction of $\mathrm{pH}$ during acidification, they can absorb to the casein micelles. Yokoyama et al. (1988) showed that by reduction of $\mathrm{pH}$ the conformation of adsorbed GT can undergo changes, producing loops and tails. Figure 3 shows these trains within yogurt network supplemented by GT. Presence of trains in yogurt matrix could reduce the interaction of casein micelles and lead to the formation of a weaker and more open structure. Presumable occurrence of trains in yogurt supplemented with lower concentrations of gum could cause bridging flocculation (Syrbe et al., 1998) and probably because of extreme proximity of casein aggregates we could not observe them in micrographs.

\section{CONCLUSIONS}

The results showed that the addition of GT did not improve the firmness and syneresis of nonfat yogurt. Yogurts stabilized with WPC showed more compact structure with more firmness and lower water drainage than control nonfat yogurt. Use of WPC in the manufacture of nonfat yogurt can improve physical and microstructural properties of nonfat yogurt. It can provide a nonfat yogurt with good physical properties that bear resemblance to that of full fat yogurt.

\section{ACKNOWLEDGMENTS}

The authors wish to thank Urmia Pegah Dairy Company for assistance with preparing milk and skim milk powder.

\section{REFERENCES}

Achanta, K., K. J. Aryana, and C. A. Boeneke. 2007. Fat free plain set yogurts fortified with various minerals. Lebensm. Wiss. Technol. 40:424-429.

Amatayakul, T., A. L. Halmos, F. Sherkat, and N. P. Shah. 2006. Physical characteristics of yoghurts made using exopolysaccharide-producing starter culture and varying casein to whey protein ratios. Int. Dairy J. 16:40-51.

Association of Official Analytical Chemists. 1997. Official Methods of Analysis. 16th ed., 3rd rev. AOAC, Arlington, VA.

Baig, M. I., and V. Prasad. 1996. Effect of incorporation of cottage cheese whey solids and Bifidobacterium bifidum in freshly made yogurt. J. Dairy Res. 63:467-473.

Beaulieu, M., Y. Pouliot, and M. Pouliot. 1999. Thermal aggregation of whey proteins in model solutions as affected by casein/whey protein ratios. J. Food Sci. 64:776-780.

Bonczar, G., M. Wszolek, and A. Siuta. 2002. The effects of certain factors on the properties of yoghurt made from ewes milk. J. Food Chem. 79:85-91.

Dannenberg, F., and H. G. Kessler. 1988a. Effect of denaturation of $\beta$-lactoglobulin on texture properties of set-style nonfat yoghurt. 1. Syneresis. Milchwissenschaft 43:632-635.

Dannenberg, F., and H. G. Kessler. 1988b. Effect of denaturation of $\beta$-lactoglobulin on texture properties of set-style nonfat yoghurt. 2. Firmness and flow properties. Milchwissenschaft 43:700-704. 
Dave, R. I., and N. P. Shah. 1998. Ingredient supplementation effects on viability of probiotic bacteria in yogurt. J. Dairy Sci. 81:2804-2816.

Donato, L., F. Guyomarc'h, S. Amito, and D. G. Dalgleish. 2007. Formation of whey protein/ $\kappa$-casein complexes in heated milk: Preferential reaction of whey protein with $\kappa$-casein in the casein micelles. Int. Dairy J. 17:1161-1167.

Everett, D. W., and R. E. McLeod. 2005. Interactions of polysaccharide stabilisers with casein aggregates in stirred skim-milk yoghurt. Int. Dairy J. 15:1175-1183.

Fiszman, S. M., M. A. Lluch, and A. Salvador. 1999. Effect of addition of gelatin on microstructure of acidic milk gels and yoghurt and on their rheological properties. Int. Dairy J. 9:895-901.

Glicksman, M. 1983. Food Hydrocolloids, Volume 2. 2nd ed. CRC Press, Boca Raton, FL.

Guyomarc'h, F., A. J. R. Law, and D. G. Dalgleish. 2003. Formation of soluble and micelle-bound protein aggregates in heated milk. Agric. Food Chem. J. 51:4652-4660.

Harte, F., L. Luedeck, B. Swanson, and G. V. Barbosa-Cánovas. 2003. Low-fat set yogurt made from milk subjected to combinations of high hydrostatic pressure and thermal processing. J. Dairy Sci. 86:1074-1082.

Havea, P., A. J. Carr, and L. K. Creamer. 2004. The roles of disulphide and non-covalent bonding in the functional properties of heatinduced whey protein gels. J. Dairy Res. 71:330-339.

Jaros, D., and H. Rohm. 2003. The rheology and textural properties of yoghurt. Chapter 13 in Texture in Food, Volume 1: Semi-solid Foods. B. M. McKenna, ed. CRC Press, New York, NY.

Kalab, M., and D. B. Emmons. 1975. Milk-gel structure. IV. Microstructure of yoghurts in relation to the presence of thickening agents. J. Dairy Res. 42:453-458.

Kalab, M., and V. R. Harwalkar. 1973. Milk gel structure. 1. Application of scanning electron microscopy to milk and other food gels. J. Dairy Sci. 56:835-842.

Keogh, M. K., and, B. T. O'Kennedy. 1998. Rheology of stirred yogurt as affected by added milk fat, protein, and hydrocolloids. J. Food Sci. 63:108-112.

Lee, W. J., and J. A. Lucey. 2004. Structure and physical properties of yogurt gels: effect of inoculation rate and incubation temperature. J. Dairy Sci. 87:3153-3164.

Lucey, J. A., P. A. Munro, and H. Singh. 1998. Rheological properties and microstructure of acid milk gels as affected by fat content and heat treatment. J. Food Sci. 63:660-664.

Lucey, J. A., C. T. Teo, P. A. Munro, and H. Singh. 1997. Rheological properties at small (dynamic) and large (yield) deformation of acid gels made from heated milk. J. Dairy Res. 64:591-600.

Madadlou, A., A. Khosroshahi, and M. E. Mousavi. 2005. Rheology, microstructure, and functionality of low-fat Iranian white cheese made with different concentrations of rennet. J. Dairy Sci. 88:3052-3062.

Mistry, V. V., and H. N. Hassan. 1991. Delactosed, high milk protein powder. 1. Manufacture and composition. J. Dairy Sci. 74:1163-1169.
Mistry, V. V., and H. N. Hassan. 1992. Manufacture of nonfat yogurt from a high milk protein powder. J. Dairy Sci. 75:947-957.

Modler, H. W., and M. Kalab. 1983. Microstructure of yogurt stabilized with milk proteins. J. Dairy Sci. 66:430-437.

Modler, H. W., M. E. Larmond, C. S. Lin, D. Froehlichand, and D. B. Emmons. 1983. Physical and sensory properties of yogurt stabilized with milk proteins. J. Dairy Sci. 66:422-429.

Pereira, R., L. Matia-Merino, V. Jones, and H. Singh. 2006. Influence of fat on the perceived texture of set acid milk gels: A sensory perspective. Food Hydrocoll. 20:305-313.

Puvanenthiran, A., R. P. W. Williams, and M. A. Augustin. 2002. Structure and visco-elastic properties of set yoghurt with altered casein to whey protein ratios. Int. Dairy J. 12:383-391.

Rahimi, J., A. Khosrowshahi, A. Madadlou, and S. Aziznia. 2007. Texture of low-fat Iranian white cheese as influenced by gum tragacanth. J. Dairy Sci. 90:4058-4070.

Sahin, H., and F. Ozdemir. 2004. Effect of some hydrocolloids on the rheological properties of different formulated ketchups. Food Hydrocoll. 18:1015-1022.

Sandoval-Castilla, O., C. Lobato-Calleros, E. Aguirre-Mandujano, and E. J. Vernon-Carter. 2004. Microstructure and texture of yogurt as influenced by fat replacers. Int. Dairy J. 14:151-159.

Schorsch, B. C., D. K. Wilkins, M. G. Jones, and I. T. Norton. 2001. Gelation of casein-whey mixtures: Effects of heating whey proteins alone or in the presence of casein micelles. J. Dairy Res. 68:471-481.

Shaker, R. R., R. Y. Jumah, and B. Abu-Jdayil. 2000. Rheological properties of plain yogurt during coagulation process: Impact of fat content and preheat treatment of milk. J. Food Eng. $44: 175-180$

Singh, H., M. S. Roberts, P. A. Munro, and C. T. Teo. 1996. Acidinduced dissociation of casein micelles in milk: Effects of heat treatment. J. Dairy Sci. 79:1340-1346.

Syrbe, A., W. J. Bauer, and H. Klostermeyer. 1998. Polymer science concepts in dairy systems-An overview of milk protein and food hydrocolloid interaction. Int. Dairy J. 8:179-193.

Tamime, A. Y., and R. K. Robinson. 1999. Yogurt: Science and Technology. 2nd ed. CRC Press, New York, NY.

Tarakci, Z., and E. Kucukoner. 2003. Physical, chemical, microbiological and sensory characteristics of some fruit-flavored yoghurt. YYU Vet Fak Dergisi 14:10-14.

Trachoo, N., and V. V. Mistry. 1998. Application of ultrafiltered sweet buttermilk and sweet buttermilk powder in the manufacture of nonfat and low fat yogurts. J. Dairy Sci. 81:3163-3171.

Tunick, M. H. 2003. Rheology of dairy foods that gels, stretch, and fracture. J. Dairy Sci. 83:1892-1898.

Weiping, W. 2000. Tragacanth and Caraya. Chapter 13 in Handbook of Hydrocolloids. G. O. Phillips, and P. A. Williams, ed. CRC Press, New York, NY.

Yokoyama, A., K. R. Srinivasan, and H. S. Fogler. 1988. Stabilization mechanism of colloidal suspensions by gum tragacanth: The influence of $\mathrm{pH}$ on stability. J. Colloid Interface Sci. 126:141-149. 